\title{
Cleaning and Disinfection of Hospital Floors
}

\author{
G. A. J. AYlifFE,* м.D., M.C.Path. ; B. J. COllinS,* A.I.M.l.T. ; E. J. L. LOWBURY,* D.m., F.C.Path.
}

Brit. med. F., 1966, 2, 442-445

Hospital floors become contaminated by settlement of airborne bacteria, by contact with shoes, trolley wheels, and other solid objects, an' occasionally by the spilling of urine, pus, sputum, and other fluids. Pathogens commonly present on the floor include Staphylococcus aureus dispersed by patients and staff, and (in much smaller numbers) Gram-negative rods, such as Pseudomonas aeruginosa. Spores of Clostridium tetani and gas-gangrene bacilli are also present on floors, probably deposited in larger numbers from shoes and trolley wheels than by deposition from the air. Some of the bacteria lie loosely in dust, while others are ingrained into the surface and between cracks.

The removal of this reservoir is one of the normal aims in the control of hospital infection. Dispersal of bacteria into the air has been greatly reduced through the replacement of brooms by vacuum cleaners in wards (Rogers, 1951; Bate, 1961 ; Babb, Lilley, and Lowbury, 1963), but vacuum cleaners and also oiled mops do not remove a large proportion of the bacteria from floors (Babb et al., 1963). Scrubbing and disinfection might be expected to have a larger effect, and useful results of disinfection are reported by Foster (1960). Finegold, Sweeney, Gaylor, Brady, and Miller (1962) and Vesley and Michaelsen (1964), on the other hand, have reported no significant difference in the reduction of bacterial counts on floors washed with detergents or with disinfectants.

We describe here a comparison of alternative methods of disinfecting and cleaning ward floors. The prompt recontamination of disinfected areas, and the consequent need to cover test areas during assessments of disinfection, became apparent during the study.

\section{Materials and Methods}

\section{Disinfectants}

A selection of agents commonly recommended for surface disinfection was investigated. The concentration chosen was $1 / 100$ of concentrate or $1 \% \mathrm{w} / \mathrm{v}$ for most of the disinfectants, but the concentration recommended by the manufacturers was used if this was markedly different.

Aqueous solutions of the following compounds were studied:

1. Phenolic compounds: Sudol $1 / 100$, Hycolin $1 / 100$, Izal $1 / 100$ and $1 / 160$.

2. Chloroxylenol: Dettol $1 / 100$ and $1 / 40$.

3. Quaternary ammonium compounds: Benzalkonium chloride (Roccal) $0.1 \%$, Cetrimide B.P. $0.1 \%$.

4. Ampholytic compound: Tego M.H.G. 1/100.

5. Combination of tri- $n$-butyltin, a quaternary ammonium compound (alkyl dimethylchlorobenzyl ammonium chloride) and isopropyl alcohol: Micro Gard with Trimicrotin 1/100.

6. A mixture containing a non-ionic detergent and a quaternary ammonium compound (alkyl dimethylbenzyl ammonium chloride): Shield $1 / 40$.

7. Chlorhexidine (Hibitane) $1 / 500$ and $1 / 5,000$.

8. Iodophors: Idokyl and Wescodyne $1 / 100$ and $1 / 160$.

9. Chlorine compounds: Domestos $1 / 100$ and $1 / 160$; chlorine cleaning powders, Diversol $\mathrm{BX} 1 \%$ and Septonite $1 \%$.

10. Ethyl alcohol $70 \%$.

* M.R.C. Hospital Infection Research Laboratory, Summerfield Hospital, Birmingham.

\section{Laboratory Tests}

A bactericidal test was used for a preliminary study of the disinfectants. The test organisms were strains of Staph. aureus and Ps. aeruginosa isolated from clinical sources. In the test $0.5 \mathrm{ml}$. of an 18-hour broth culture of the test organism was added to $4.5 \mathrm{ml}$. of disinfectant solution at room temperature. Three standard loopfuls were transferred to an agar plate, and one loopful to $2 \mathrm{ml}$. of nutrient broth at intervals of $1,2 \frac{1}{2}, 5$, and 10 minutes. The inoculated plates and broth were incubated at $37^{\circ} \mathrm{C}$. for 24 hours, and the broths were then subcultured on to agar plates which were incubated at $37^{\circ} \mathrm{C}$. for 24 hours. The minimum time of exposure after which no growth was obtained on the agar plate or in the tubes of broth was recorded. The tests were repeated with $20 \%$ serum added to the disinfectant solutions before addition of the organisms. Egg-yolk Tween 80 agar plates, and egg-yolk Tween 80 broth (Morris and Darlow, 1959), were used for sampling quaternary ammonium and Tego compounds. Sodium thiosulphate $0.5 \%$ was added to the nutrient broth for sampling iodine and chlorine compounds. To exclude the possibility of carry-over of a bacteriostatic amount of disinfectant, tubes of broth showing no growth were inoculated with one drop of a suspension of Staph. aureus (approximately 10 organisms) and examined for growth after 18 hours' incubation at $37^{\circ} \mathrm{C}$.

\section{Surface Disinfection Tests}

The effect of cleaning a contaminated glass plate and a similarly contaminated floor covered with polyvinyl tiles with a disinfectant or a detergent was investigated. A glass plate 32 by 22 in. ( 81 by $56 \mathrm{~cm}$.) was divided into 15 squares. Six randomly selected squares were inoculated with five standard loopfuls of a suspension of organisms in horse serum $\left(5 \times 10^{9}\right.$ orgs. $/ \mathrm{ml}$.). Three of these squares were inoculated with Staph. aureus, and the other three squares with Ps. aeruginosa (the same strains as in the last experiment). After drying for one hour one square inoculated with Staph. aureus, and another with $P$ s. aeruginosa, were sampled with moistened throat swabs. A pad of cotton-wool (approximately 2 by 2 by 1 in. ( 5 by 5 by $2.5 \mathrm{~cm}$.) was immersed in disinfectant or detergent, excess fluid was drained off, and the whole surface of the glass plate was thoroughly cleaned with the pad. After drying the other four contaminated squares were sampled by rubbing over the surface of each with a throat swab moistened with a solution containing lecithin, Lubrol, and sodium thiosulphate (Lowbury and Lilly, 1960). The swabs were inoculated on to nutrient agar or egg Tween 80 agar and incubated at $37^{\circ}$ for 48 hours. Similar tests were also made on a floor covered with polyvinyl tiles.

\section{Ward Study}

\section{Sampling Techniques}

Floors were sampled with agar impression plates (Foster, 1960 ; Babb et al., 1963), each plate covering an area of 9.6 sq. in. (62 sq. cm.). Phenolphthalein diphosphate was added to the agar to obtain presumptive counts of Staph. aureus (Barber and Kuper, 1951); egg yolk and Tween 80 were 
added to plates for tests with Tego and quaternary ammonium compounds. Counts of total organisms and presumptive Staph. aureus were made after 24 hours' incubation at $37^{\circ} \mathrm{C}$. Tests for carry-over of disinfectant were also made by adding drops of a suspension of Staph. aureus (approximately 10 organisms/drop) to impression plates which showed little or no growth after sampling a treated floor; there was no inhibition of growth from these inocula.

\section{Floor-cleansing}

The experiments were performed in a 28 -bedded male surgical ward with a terrazzo floor.

Experiment 1.-The ward floor was swept with a broom and mopped with soap and water or disinfectant solution by ward cleaners at 7 a.m. according to the usual routine. Measured quantities of neat disinfectant were supplied to the cleaners in bottles and added to a bucket of hot water to give the required concentration. The floors were sampled one hour and nine hours after mopping. Six impression plates were used for each test, and tests were repeated daily with each disinfectant for three or five days. Tests were made with soap and water, Shield, Tego M.H.G., and Sudol.

Experiment 2.-In Experiment I the high total bacterial counts obtained one hour after cleaning with a disinfectant suggested either heavy recontamination or ineffective disinfection. To solve this problem the following tests were made. Four impression plates were taken from an area of floor, which was then mopped with soap and water or disinfectant by the ward-cleaner. The mop and bucket were rinsed in the solution before use and a fresh solution was used for the floor treatment. A cardboard box (15 by 9 by 9 in. ; 38 by 23 by $23 \mathrm{~cm}$.) open on one side was placed on the treated floor with the open side downwards to prevent recontamination. After one hour two impression-plate samples were taken from the area covered by the box, and two plates were also taken from an adjacent treated but uncovered area. Two settle plates were exposed on top of the box during the test period. Tests were made with soap and water and 10 disinfectants.

Experiment 3.-Further tests were made with the use of the box to compare the effectiveness of soap and water, Tego, Micro Gard, Hycolin, and Sudol. Mops were used for all tests except the one in which a Cimex Eagle combined scrubbing and vacuum-drying machine was used with a detergent. Six impression plates were taken from a selected area of floor, which was then treated as in Experiment 2, and the open cardboard box was inverted over part of the treated floor. After one hour six impression plates were taken from the area covered by the box. Two tests were performed with each cleaning agent in the experiments with mops, and one test with the scrubbing-and-drying machine.

\section{Results}

\section{Bactericidal Tests}

Table I shows the minimum exposure time required to kill a single strain each of Staph. aureus and Ps. aeruginosa with and without the addition of $20 \%$ serum to the disinfectant. The results indicate that in these tests most of the disinfectants were effective against both organisms in the absence of organic matter. Sudol, Izal, and $0.2 \%$ chlorhexidine were effective against both organisms in one minute in the presence of $20 \%$ serum. Shield was slightly less effective against Staph. aureus in the presence of serum, and the other quaternary ammonium compounds were less effective against Ps. aeruginosa in the presence of serum. Tego and the chlorine compounds were less effective against Staph. aureus than against Ps. aeruginosa. The iodophors, the chlorine compounds, Tego, and to a less extent Hycolin showed reduced activity in the presence of serum. An unexpected finding was the greater activity of Dettol against Ps. aeruginosa than against Staph. aureus; preliminary tests with another chloroxylenol preparation (D.C.M.X.) had shown that this had poor activity against Ps. aeruginosa. Activity of Dettol against both organisms was reduced in the presence of serum. Chlorhexidine at a dilution of $0.02 \%$ was less effective against either organism than most of the other disinfectants tested.

TABLE I.-Time in Minutes Taken to Kill Strains of Staph. aureus and Ps. aeruginosa in Solutions of Disinfectants

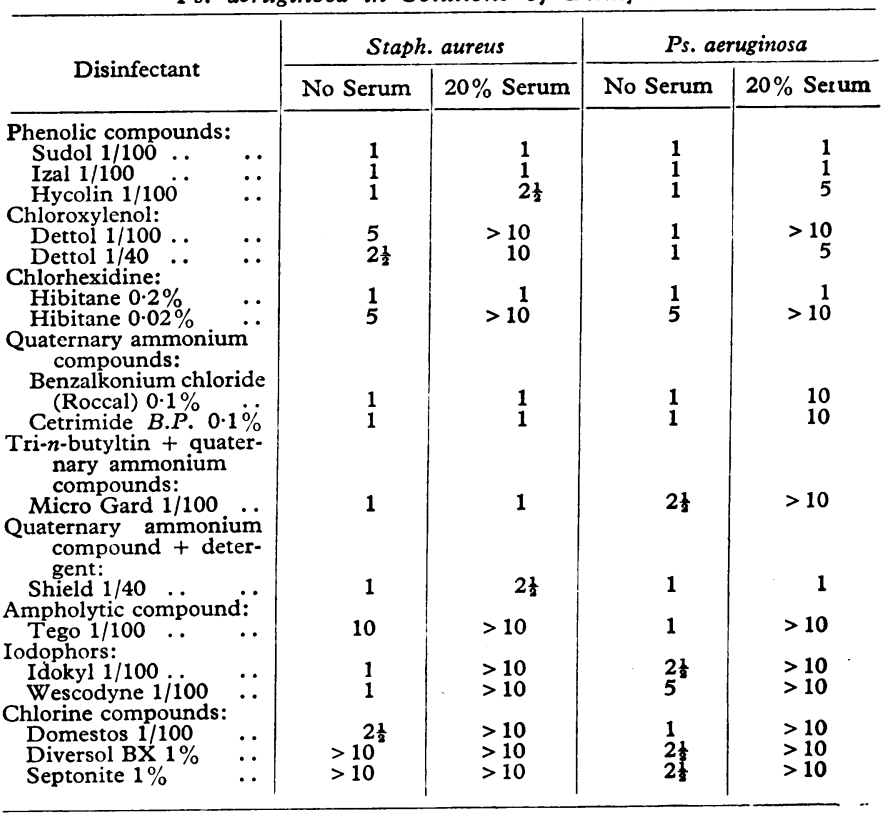

\section{Surface Disinfection Tests}

Ps. aeruginosa was not isolated from the glass plate after cleaning with any of the disinfectants or with a non-ionic detergent alone. Sudol 1/100, Izal $1 / 100$, Hycolin $1 / 100$, Dettol $1 / 40$, Roccal $0.1 \%$, cetrimide $0.1 \%$, Micro Gard $1 / 100$, Shield 1/40, Tego 1/100, Domestos 1/100, Idokyl 1/100, ethyl alcohol $70 \%$, chlorhexidine $0.2 \%$, and Diversol BX $1 \%$ were all effective against Staph. aureus, and no growth was obtained from the plate after treatment with these disinfectants. Staph. aureus was still isolated in large numbers from all squares following the use of $0.02 \%$ chlorhexidine and of a non-ionic detergent. Similar results were obtained with polyvinyl tiles as with the glass plate. The results indicate that cleaning with detergent alone, followed by drying, was sufficient to kill or remove Ps. aeruginosa, and that similar treatment with all but one of the disinfectants, even if their activity is reduced by serum, was also effective against Staph. aureus. Cleaning with detergent alone was not sufficient to remove or kill Staph. aureus present in dried serum.

\section{Ward Tests}

The results obtained from Experiment 1 are shown in Table II. The total counts of impression plates taken one hour

TABLE II.-Mean Bacterial Counts on Impression Plates from Ward

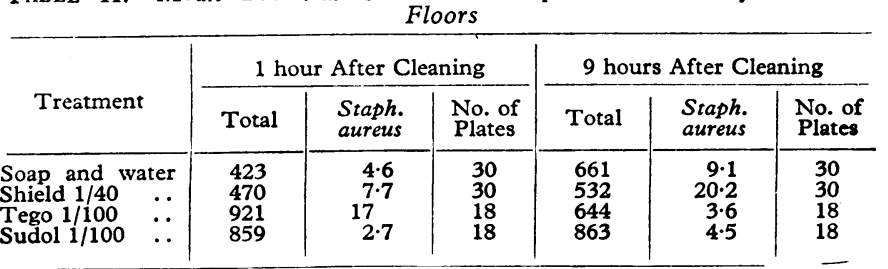


after cleaning were very high, and indicate rapid and heavy recontamination. With Sudol the mean total counts at nine hours were the same as at one hour; they were slightly higher with soap and water and with Shield, and lower with Tego. When recontamination was prevented by protecting an area of floor with a box, as in Experiment 2, a considerable reduction in total bacterial counts and a reduction in the numbers of Staph. aureus was found one hour after all methods of cleaning. Table III shows a reduction of $89.7 \%$ in bacterial counts with soap and water, and reduction of 93.7 to $99.9 \%$ following the use of disinfectants. The counts of samples taken from a treated area outside the box were much higher, indicating recontamination and an absence of continuing disinfection after drying. The counts from the uncovered area were variable, and lower than those obtained in Experiment 1, as the tests in Experiment 2 were performed at a time of less ward activity. Settle plates exposed on the box during the test (one hour) showed an average of 59 colonies/plate.

TABLE III.-Effects of Clraning and Disinfection on Exposed and Covered Areas of Ward Floor

\begin{tabular}{|c|c|c|c|c|c|c|c|}
\hline \multirow{4}{*}{ Treatment } & \multicolumn{6}{|c|}{ Mean Bacter:al Counts } & \multirow{4}{*}{$\begin{array}{c}\text { o Reduc- } \\
\text { tion (Total } \\
\text { Organisms) } \\
\text { After } \\
\text { Treatment: } \\
\text { Covered } \\
\text { Areas }\end{array}$} \\
\hline & \multicolumn{2}{|c|}{$\begin{array}{c}\text { Before } \\
\text { Treatment }\end{array}$} & \multicolumn{4}{|c|}{ After Treatment } & \\
\hline & \multirow[b]{2}{*}{ Total } & \multirow{2}{*}{$\begin{array}{l}\text { Staph. } \\
\text { aureus }\end{array}$} & \multicolumn{2}{|c|}{ Floor Exposed } & \multicolumn{2}{|c|}{ Floor Covered } & \\
\hline & & & Total & $\begin{array}{l}\text { Staph. } \\
\text { aureus }\end{array}$ & Total & $\begin{array}{l}\text { Staph. } \\
\text { aureus }\end{array}$ & \\
\hline $\begin{array}{lc}\text { Sudol } 1 / 100 & \ldots \\
\text { Izal 1/160 } & \ldots \\
\text { Dettol 1/40 } & \cdots \\
\text { Hycolin 1/100 } & \ldots \\
\text { Micro Gard } & 1 / 100 \\
\text { Shield } 1 / 40 & \ldots \\
\text { Tego 1/100 } & \ldots \\
\text { Idokyl } 1 / 160 & \ldots \\
\text { Domestos } & 1 / 160 \\
\text { Diversol BX } & 1 \% \% \\
\text { Soap and water.. } \\
\text { Soap and }\end{array}$ & $\begin{array}{l}190 \\
945 \\
445 \\
261 \\
788 \\
210 \\
400 \\
267 \\
162 \\
830 \\
397\end{array}$ & $\begin{array}{c}4 \cdot 5 \\
4.5 \\
1 \cdot 2 \\
2 \cdot 8 \\
24 \\
0 \cdot 3 \\
0 \\
0 \\
2 \cdot 5 \\
8 \cdot 5 \\
13\end{array}$ & $\begin{array}{r}75 \\
179 \\
144 \\
221 \\
261 \\
142 \\
684 \\
79 \\
120 \\
243 \\
460\end{array}$ & $\begin{array}{l}0 \\
3 \\
1 \\
2 \cdot 5 \\
0 \cdot 5 \\
1 \\
0 \\
0 \\
6 \\
2 \cdot 5 \\
3\end{array}$ & $\begin{array}{c}2 \cdot 5 \\
9 \\
5 \cdot 5 \\
16 \cdot 5 \\
1 \\
2 \cdot 5 \\
24 \\
6 \\
5 \\
18 \cdot 5 \\
41\end{array}$ & $\begin{array}{l}0 \\
0 \cdot 5 \\
0 \\
0 \cdot 5 \\
0 \\
0 \\
0 \\
0 \\
0 \\
0 \cdot 5 \\
0\end{array}$ & $\begin{array}{l}98 \cdot 7 \\
99 \cdot 1 \\
98 \cdot 8 \\
93 \cdot 7 \\
99 \cdot 9 \\
98 \cdot 8 \\
94.8 \\
97 \cdot 8 \\
96 \cdot 9 \\
97 \cdot 3 \\
89 \cdot 7\end{array}$ \\
\hline
\end{tabular}

The results of Experiment 3 are shown in Table IV. They confirm with a larger series of observations the results obtained in Experiment 2 with soap and water, Sudol, Micro Gard, Hycolin, and Tego. A significant reduction in the mean of total organisms was obtained after cleaning the floor with soap and water $(t=9.16, P<0.001)$. The mean bacterial counts obtained after using disinfectants were significantly lower than those obtained with soap and water (Sudol: $t=10.7, P<0.001$; Micro Gard: $\mathrm{t}=11.6, \mathrm{P}<0.001$; Hycolin: $\mathrm{t}=8.6, \mathrm{P}<0.001$; Tego: $\mathrm{t}=8.3, \mathrm{P}<0.001$ ).

The mean bacterial counts from the floor after cleaning with Sudol and with Micro Gard were significantly lower than that obtained with Tego (Sudol: $t=3.6, P<0.01 ;$ Micro Gard : $t=4.8, P<0.001$ ).

In the experiment with a Cimex Eagle combined scrubbing and vacuum-drying machine the mean reduction by use of detergent was $80.7 \%$ (approximately the same as that obtained with a mop and soap and water).

\section{Discussion}

The bacteria in an area of terrazzo hospital-ward floor protected from recontamination were greatly reduced in numbers after each of the methods of cleaning and disinfection tested. In contrast with the $40-50 \%$ reduction in floor bacteria obtained by using dry methods (a vacuum cleaner or oiled mops) (Babb et al., 1963), washing with soap and water or a detergent, either with a mop or with a combined scrubbing and vacuum-drying machine, caused a reduction of about $80 \%$, and much larger effects were obtained with disinfectants. The most active agents tested caused a reduction of over $99 \%$, and all the disinfectants included in our study had an appreciably greater effect than soap and water. The value of disinfectants in removing bacteria from a floor corresponded in most cases with their performance in killing Staph. aureus in tube tests and on a glass plate-for example, Sudol and Micro Gard were highly active, and the halogens (hypochlorite and iodophor solutions), which are rapidly inactivated by organic matter, were less effective in both laboratory and field tests. Hycolin and Tego had an intermediate position in laboratory tests, but were the least successful in field tests. Though Staph. aureus was present in the laboratory test after five minutes' exposure to Tego, exposures of one, two and a half, and five minutes showed a considerable reduction in their numbers.

Organic tin compounds have been claimed to exert a continuing antibacterial action after use, as a result of which surfaces can be kept relatively free from contamination (Hudson, Sanger, and Sproul, 1959). The claim was not supported in studies by Finegold et al. (1962), or Kingston and Noble (1964), or in our studies, which showed as much recontamination on unprotected areas of floor treated with Micro Gard as on unprotected areas treated with other disinfectants or with soap.

The benefit of removing bacteria from ward floors is largely annulled by the rapid recontamination of these surfaces. This has also been shown by Vesley and Michaelsen (1964), though the rate of recontamination in their experiment was less than in the present study. Because of the apparent failure of disinfectants to disinfect, some authorities hold that it is probably not worth while using them for the cleaning of floors except when there is severe contamination (Report, 1965). But since the level of bacteria in any environment is determined by a balance of acc ction and elimination, the use of disinfectants must have some value, even if it is not apparent in places where the rate of recontamination is high; this condition obviously occurs in certain wards, especially during and after cleaning rounds, when there is maximum activity and movement of beds.

Our results emphasize the need to prevent recontamination of floors from the air, and from contact with shoes and other objects. Oiling of bedclothes was shown by van den Ende and Spooner (1941) to reduce the dispersal of bacteria. With the change from woollen to boilable cotton blankets, and the introduction of vacuum cleaners in wards, the practice of oiling blankets and floors was quietly abandoned. Experience on the value of dust-laying in preventing cross-infection has varied (Wright, Cruickshank, and Gunn, 1944 ; Clarke, Dalgleish, Parry, and Gillespie, 1954). A reassessment of methods which prevent the dispersal of bacteria from bedclothes, including cotton cellular blankets, would be useful. Other sources may be still more important, especially the dispersal of epithelial scales (Davies and Noble, 1962); a more widespread use of antiseptic soaps by staff and patients might be expected to reduce this source of contamination.

There is uncertainty about the role of floor bacteria as a source of hospital infection, but it is rational, when practicable, to prevent the establishment of reservoirs of pathogenic bacteria

\begin{tabular}{|c|c|c|c|c|c|c|c|c|}
\hline \multirow{2}{*}{\multicolumn{2}{|c|}{ Treatment }} & \multicolumn{3}{|c|}{ Before Treatment } & \multicolumn{3}{|c|}{1 hour After Treatment, Floor Covered } & \multirow{2}{*}{$\begin{array}{c}\% \text { Reduction } \\
\text { Total } \\
\text { Organisms }\end{array}$} \\
\hline & & Total & Staph. aureus & No. of Plates & Total & Staph. aureus & | No. of Plates | & \\
\hline 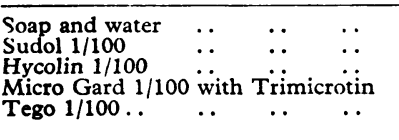 & $\begin{array}{l}. . \\
\because \\
\cdots\end{array}$ & $\begin{array}{r}699 \cdot 8 \pm 60 \cdot 4 \\
1,242 \pm 144 \cdot 1 \\
364 \cdot 2 \pm 34 \cdot 9 \\
905 \cdot 7 \pm 136 \cdot 0 \\
880 \cdot 8 \pm 121 \cdot 0\end{array}$ & $\begin{array}{r}1.7 \\
1.7 \\
7.4 \\
22.6 \\
10.1\end{array}$ & $\begin{array}{l}12 \\
12 \\
12 \\
12 \\
12\end{array}$ & $\begin{array}{l}137 \pm 10 \cdot 7 \\
12.6 \pm 4 \cdot 3 \\
21.6 \pm 0.5 \\
8.5 \pm 2.6 \\
37.5 \pm 5.4\end{array}$ & $\begin{array}{l}1 \cdot 4 \\
0 \\
0 \cdot 3 \\
0 \cdot 17 \\
3 \cdot 1\end{array}$ & $\begin{array}{l}12 \\
12 \\
12 \\
12 \\
12\end{array}$ & $\begin{array}{l}80 \cdot 4 \\
99 \cdot 0 \\
94 \cdot 1 \\
99 \cdot 0 \\
95 \cdot 7\end{array}$ \\
\hline
\end{tabular}


and to remove such reservoirs. The majority of disinfectants tested at the chosen concentration appeared to be highly effective in this respect. The tests were carried out by using one concentration of disinfectant on terrazzo flooring in one ward, and it is possible that different results might be obtained under other conditions. In the selection of a disinfectant for floor treatment its activity against the range of pathogens in the reservoir, its safety, acceptability in use, aesthetic results, and cost must be considered ; the type of flooring is also relevant, because materials used for flooring may be damaged by some compounds. Some disinfectants which were highly active against Staph. aureus but less active against Ps. aeruginosa in laboratory tests were effective in field tests, and our experiments suggest that $P$ s. aeruginosa could be successfully removed from surfaces by cleaning with these agents ; as a result of their high death rate on drying, these organisms, when present in floor dust, are very scanty and are probably further depleted by the evaporation of solutions used for disinfecting the floor. Chlorine compounds, though better than soap and water, were less effective than the best of the disinfectants. Phenolic compounds varied in their effectiveness ; the best of these, however, showed highly satisfactory results both in laboratory and in field tests.

Toxicity will also affect the choice of a disinfectant ; many phenolic compounds-for example, Lysol and to a less extent Sudol-and tri- $n$-butyltin compounds may be corrosive, particularly in high concentration, and should be handled with care.

In testing the effectiveness of a new method of disinfection it is perhaps reasonable to require that it shall reduce the total floor bacteria on areas protected from recontamination by about $95-99 \%$, or to fewer than 15 bacterial colonies and less than one colony of Staph. aureus per impression plate.

\section{Summary}

After preliminary assessments of bactericidal action by 14 disinfectants, the ability of selected agents to remove bacteria from hospital-ward floors was studied and compared. The disinfectants included phenolic, quaternary ammonium, and ampholytic compounds, a tri- $n$-butyltin compound, a chloroxylenol, chlorhexidine, iodophors, chlorine compounds and cleaning powders, and $70 \%$ ethyl alcohol.
Impression-plate samples showed little or no reduction in total bacteria or in Staph. aureus on exposed floors after washing or disinfection; but when an area of floor was protected from recontamination by inverting an open box over the area, large reductions in total bacterial counts were found, and Staph. aureus was reduced or eliminated after such treatment. Soap and water caused a mean reduction of $80 \%$ and disinfectants caused a mean reduction of $93-99 \%$ in bacterial counts on areas protected from recontamination. These effects were highly significant, as were the differences between detergent washing and disinfection; significant differences between certain disinfectants were also found. All of these treatments caused a much larger reduction in bacteria than had been found in earlier studies with dry methods (vacuum cleaners and oiled mops).

Since the benefits of disinfection are frustrated by recontamination, it is necessary also to reduce the access of bacteria by air and by contact if floors are to be kept bacteriologically clean.

We wish to thank Miss Sandra Louis and Mr. M. Wilkins for technical assistance, the Matron and Domestic Supervisor of Dudley Road Hospital for their co-operation, and the manufacturers for supplies of disinfectants.

\section{REFERENCES}

Babb, J. R., Lilly, H. A., and Lowbury, E. J. L. (1963). F. Hyg. (Lond.). 61, 393.

Barber, M., and Kuper, S. W. A. (1951). F. Path. Bact., 63, 65.

Bate, J. G. (1961). Lancet, 1, 159.

Clarke, S. K. R., Dalgleish, P. G., Parry, E. W., and Gillespie, W. A. (1954). Ibid., 2, 211 .

Davies, R. R., and Noble, W. C. (1962). Ibid., 2, 1295.

Finegold, S. M., Sweeney, E. E., Gaylor, D. W., Brady, D., and Miller, L. G. (1962). Antimicrobial Agents and Chemotherapy, p. 250.

Foster, W. D. (1960). Lancet, 1, 670.

Hudson, P. B., Sanger, G., and Sproul, E. E. (1959). F. Amer. med. Ass., 169, 1549 .

Kingston, D., and Noble, W. C. (1964). 7. Hyg. (Lond.), 62, 519.

Lowbury, E., J. L., and Lilly, H. A. (1960). Brit. med. 丹., 1, 1445.

Lowbury, E. J. L., and Lilly, H. A. (1960). Brit. med. F., 1, 1445

Morris, E. J., and Darlow, H. M. (1959). f. appl. Bact., 22, 64.

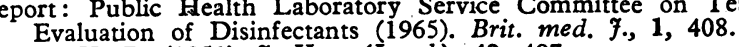

Rogers, K. B. (1951). ₹. Hyg. (Lond.), 49, 497.

van den Ende, M., and Spooner, E. T. C. (1941). Lancet, 1, 751.

Vesley, D., and Michaelsen, G. S. (1964). Hlth Lab. Sci., 1, 107.

Wright, Joyce, Cruickshank, R., and Gunn, W. (1944). Brit. med. 3., 1, 611 .
Dr. G. F. Taylor (Brit. med. F., 1964, 2, 1597) has drawn attention to the restriction of vision which is imposed by certain modern kinds of spectacle frame. Personal observation made by us has also revealed that some drivers wearing spectacle frames with wide shafts and lens mounts were occasionally unaware of overtaking traffic.

It was therefore decided to carry out a simple objective and subjective investigation of the relative effects of different kinds of spectacle frames. Fourteen types were selected from the stock of a retail optician. The choice was made with the advice of the manager, Mr. Pipe, of the Hay Hill branch of Messrs.

\footnotetext{
* Consultant, Road Research Laboratory, Ministry of Transport. t Reader in Physiological Optics, Institute of Ophthalmology, University
of London.
}

Newbold, because he was aware of those frames which are currently popular for both ordinary and sun spectacles. The selected items included examples of most of the frames supplied through the National Health Service.

These frames vary widely in the subjective obstruction to vision, which clearly will depend on different eye positions. It was thought that from the point of view of driving the worst effects would be due to the obstruction of central rather than peripheral vision, since much of the peripheral field is obstructed by the surrounding car body. It is known that in Great Britain $10 \%$ of vehicle accidents occur following manœuvres which involve turning right, either from a standstill position at the roadside or during overtaking manœuvres, as well as turning across oncoming traffic at a crossroads or 